\title{
The influence of base oil type on the rheological properties of ecological lubricating greases
}

\author{
Wpływ rodzaju bazy olejowej na właściwości reologiczne ekologicznych smarów \\ plastycznych
}

\author{
Rafał Kozdrach \\ Łukasiewicz Research Network - The Institute for Sustainable Technologies
}

\begin{abstract}
The article presents the results of research on the influence the type of base oil in lubricating compositions has on the rheological parameters of selected lubricants. Vegetable, mineral, and synthetic dispersion phases were used to produce lubricating greases. The modified amorphous silica was used as the dispersed phase. However, as a modifying additive was used a substance containing the antioxidants, corrosion inhibitors, and EP/AW additives. The experiments on rheological properties were carried out using a Physica MCR 101 rotational rheometer (manufactured by Anton Paar), equipped with a diffusion air bearing and connected to a pneumatic supply - an oil-free Jun-Air compressor and air drying block. The device is equipped with a Peltier system for temperature control in the range of $-20^{\circ} \mathrm{C}$ to $200^{\circ} \mathrm{C}$ and an external thermostatic VISCOTHERM V2 system, working in the temperature range of $-20^{\circ} \mathrm{C}$ to $200^{\circ} \mathrm{C}$. The rheometer control and measurement data analysis were performed using Rheoplus software. The tests were carried out using a cone-plate measuring system with a shear rate range of $0.01-100 \mathrm{~s}^{-1}$ at $20^{\circ} \mathrm{C}$ for lubricating compositions prepared on various oil bases. To evaluate the value of rheological parameters, the results of tests of the dependence between shear stress and shear rate (flow curves) were used. For the theoretical determined on the flow curves, the following rheological models were used: Bingham, Herschel-Bulkley, Casson, and Tscheuschner. The values of the shear stress (yield point) in depending on the type of dispersion phase has changed. This proves that the use of a base oil with the appropriate functional properties does not weaken, but reinforces the spatial structure of a lubricating grease. It has an important meaning when selecting construction parameters when designing a central lubrication system with grease made from a vegetable oil base (Abyssinian oil). The rheological properties of the lubricating grease are influenced by the type of base oil and thickener, any additives in the grease, the production technology of the grease, and the conditions in which it is used. The tests revealed an important influence of the base oil on the rheological parameters that describe the behaviour of lubricating compositions subjected to stresses and strains in a lubricating system.
\end{abstract}

Key words: lubricating grease, base oil, rheological properties, flow curve, yield point, rotational rheometer.

STRESZCZENIE: W artykule przedstawiono wyniki badań wpływu rodzaju bazy olejowej kompozycji smarowych na wartości parametrów reologicznych badanych środków smarowych. Do wytworzenia smarów plastycznych zastosowano roślinną, mineralną i syntetyczną fazę dyspergującą. Jako fazę zdyspergowaną wykorzystano modyfikowaną krzemionkę amorficzną. Natomiast jako dodatku modyfikującego użyto substancji zawierającej w swoim składzie przeciwutleniacze, inhibitory korozji oraz dodatki EP/AW. Badania doświadczalne właściwości reologicznych wykonano za pomocą reometru rotacyjnego Physica MCR 101 (prod. Anton Paar), zawierającego dyfuzyjne łożysko powietrzne, podłączone do zasilania pneumatycznego - bezolejowego kompresora Jun-Air oraz bloku osuszającego powietrze. Aparat wyposażony jest w układ Peltiera kontroli temperatury w zakresie od -40 do $-200^{\circ} \mathrm{C}$ oraz w zewnętrzny układ termostatujący Viscotherm V2, pracujący w zakresie temperatur od -20 do $-200^{\circ} \mathrm{C}$. Sterowanie reometrem oraz analizę danych pomiarowych przeprowadzono za pomocą oprogramowania Rheoplus. Badania wykonywano, stosując układ pomiarowy stożek-płytka, w zakresie szybkości ścinania $0,01-100 \mathrm{~s}^{-1} \mathrm{w}$ temperaturze $20^{\circ} \mathrm{C}$ dla kompozycji smarowych wytworzonych na różnych bazach olejowych. Do oceny wartości parametrów reologicznych wykorzystano wyniki badań zależności naprężenia ścinającego od szybkości ścinania (tzw. krzywe płynięcia). Do teoretycznego wyznaczenia krzywych płynięcia zastosowano następujące modele reologiczne: Binghama, Herschela-Bulkleya, Cassona oraz Tscheuschnera. Wartość naprężenia ścinającego (granicy plastyczności) ulegała zmianie w zależności od rodzaju użytej fazy dyspersyjnej. Dowodzi to, że zastosowanie w smarze bazy olejowej o odpowiednich właściwościach użytkowych nie osłabia, ale wzmacnia jego strukturę przestrzenną. Ma to istotne znaczenie w doborze parametrów konstrukcyjnych przy projektowaniu układu centralnego smarowania z kompozycjami smarnymi na bazie oleju roślinnego. Na właściwości reologiczne smaru plastycznego wpływa zarówno rodzaj oleju bazowego i zagęszczacza, jak i dodatek dodawany do smaru, technologia

Corresponding author: R. Kozdrach, e-mail: rafal.kozdrach@itee.lukasiewicz.gov.pl

Article contributed to the Editor: 11.08.2020. Approved for publication: 28.01.2021 
jego wytwarzania, a także warunki, w jakich smar był stosowany. Przeprowadzone badania wykazały istotny wpływ bazy olejowej na wartości parametrów reologicznych opisujących zachowanie badanych kompozycji smarowych poddanych naprężeniom i odkształceniom w układzie smarowniczym.

Słowa kluczowe: smar plastyczny, olej bazowy, właściwości reologiczne, krzywa płynięcia, granica płynięcia, reometr rotacyjny.

\section{Introduction}

The properties of a lubricating grease are shaped by its structure, which results from the proportions of the dispersing phase, thickener, and modifying additives in its composition. The dispersing phase (base oil) usually accounts for $70-90 \%$ of the volume of the final product and is used together with the thickener to form a lubricating grease (Bartz, 1998, 2006; Fox and Stachowiak, 2003). The base oils are of mineral (petroleum products), synthetic (chemically synthesised products of hydrocarbon and non-hydrocarbon oils), or vegetable origin (Kato et al., 1998; Tuszyński et al., 2014). As the main component of a lubricating grease, the base oil determines a number of useful properties of the resulting lubricating compositions. Its role is to provide lubricants with good lubricating properties, resistance to oxidation and temperature, miss appropriate rheological properties, and minimal chemical reactivity (it should not react with other grease components) (Beran, 2008; De Laurentis et al., 2017; Drabik et al., 2018c). To meet the growing requirements for the quality of base oils with improved properties, producers have started introducing refining additives. Lubricating greases intended for the food industry should be an ecological character, starting with a significant reduction of the content of toxic chemical substances, because these greases must be non-toxic and highly biodegradable (Jamadar and Vakharia, 2016; Fisher et al., 2018). The production of lubricants with appropriate properties requires the use of components, in particular base oils, which impart these properties on the final product, that it doesn't create a threat to the natural environment (Casserly et al., 2004; Florea et al., 2006; Sanchez et al., 2009).

The aim of rheology is to be able to predict the behaviour of a fluid on the system of forces applied to it, or to predict the system of forces that will cause a specific fluid behaviour. The rheological behaviour of a material is described by the relationship between stresses, strains, and the speed of these strains (Delgado et al., 2005; Singh et al., 2018). The main test work of rheology is to develop models for describing the behaviour of fluids subjected to a force. The behaviour of ideal solids and liquids can be described in the form of mathematical models, including the relationship between stresses, deformations, or strain speeds and the rate of stress increase (Cousseau et al., 2012). However, the rheological equations describe ideal fluids, which do not exist in reality.
Rheology can be divided into micro- and macrorheology. Microrheology, which is an area of interest to physicochemists, considers the relationships that occur between the real structure of matter (e.g. the internal structure of polymers) and its properties. Macrorheology involves the behaviour of a system (e.g. a suspension) as a whole, under the influence of a system of applied forces. Rheology (from the Greek words rheo [flow] and logos [science]) is a science that it studies the aspects of the deformation of real fluids under the influence of stresses applied to them (Solomon et al., 2001; Delgado et al., 2008; Pham et al., 2008). In rheological research, we are not interested in fluid motions as a whole, but in the motion of some elements of this fluid relative to others. Rheology describes the phenomena that occur in the very broad area between solid and liquid states, which in classical mechanics are considered separately. In other words, rheology occurs in real fluids that are subjected to deformation, showing more than one basic property, i.e. viscosity or elasticity (Delgado et al., 2006a, 2006b). From a rheological point of view, the rheological properties of the media or other substances are usually of interest to us only when it affects a technological process or when we are interested in the impact the process has on the rheological properties of the substance that determine the functional values of the manufactured product (Song et al., 2009; Martin-Alonso et al., 2013).

Research into the rheological properties of substances has provided many basic data that are necessary in the design of pipelines, pumps, mixers, plastic processing equipment, homogenisers, etc. to control their quality and stability (durability) during the transport and used of many intermediate products and the final product obtained through the production process (Delgado et al., 2008; Song et al., 2009). For this reason, rheological tests of substances with complex properties are carried out in the ceramics industry (casting slurries or plastic masses for extrusion or injection), plastics (polymer solutions or melted polymers), the paper industry (paper pulp), cosmetics, paints, varnishes, pharmaceutics, food, and others (Kavehpour and McKinley 2004; Wyss et al., 2007). Rheometric research is also used in many fields of science, e.g. in soil mechanics, process engineering, environmental engineering, biotechnology, bioengineering, and more. It is worth remembering that even a slight improvement in the handling of substances obtained through the use of rheometric tests can lead to measurable economic benefits in relation to high-volume production 
(Delgado et al., 2006b; Wyss et al., 2007; Cousseau et al., 2012). There are four basic directions of rheological research: the phenomenological rheology or macrorheology, which describes phenomena occurring during the deformation of real fluids on a macro scale, but ignores the molecular structure; structural rheology or microrheology, which studies the relationship between the structure of a substance at the micro level and its rheological properties; rheometry, which empirically determines the rheological parameters that characterise the properties of Newtonian and non-Newtonian fluids; and technical or applied rheology, which describes fluid flow in processes of practical meaning, e.g. mixing, extrusion, sedimentation, fluid transfer, etc. (Delgado et al., 2005; Pham et al., 2008; Song et al., 2009; Esteban et al., 2012).

\section{Materials and research methodology}

The lubricating compositions were developed using nontoxic components to constitute the dispersion and dispersed phases. As a dispersion phase, vegetable oils and mixtures of vegetable and mineral oils with the best tribological and physicochemical properties were used (Drabik et al., 2018b; Iłowska et al., 2018; Szmatoła et al., 2018; Kozdrach, 2020). Abyssinian oil was used as a vegetable oil because it is an inedible oil and has very good physicochemical, tribological, and rheological properties. Modified amorphous silica was used as a dispersed phase (Drabik et al., 2017; Kozdrach, 2017, 2018). As a modified additive, a substance containing antioxidants, corrosion inhibitors, and EP/AW additives
(Brad Chem 351) was used. The lubricating greases were prepared from the selected components for use in the agrifood industry: based on Abyssinian oil (grease A), based on Abyssinian oil with a modified additive (grease B), based on a mixture of Abyssinian oil and SpectraSyn oil (grease C), based on a mixture of Abyssinian oil and SpectraSyn oil with a modified additive (grease D), and based on a mixture of Abyssinian and paraffin oil (grease E). Various amounts of the thickener, i.e. amorphous silica, were introduced into the tested lubricants. In the early phase of the research, experiments were carried out on the amount of thickener which would be included in the lubricating composition. The tests were carried out with formulas containing from $5 \%$ to $8 \%$ of the dispersed phase. The lubricating compositions prepared in this way were subjected to rheological tests.

The chemical compositions of the tested lubricating greases are presented in Table 1.

The physicochemical properties of the mixtures of oils used in the tests are presented in Table 2.

An MCR-101 rotational rheometer with air bearing by Anton Paar was used to determine the rheological properties of the tested lubricating greases. The rheometer control and measurement have data analysis were carried out using Rheoplus software. The measurements were taken using a cone-plate measuring system. The zero gap at the testing temperature was set for the selected measuring system. This procedure was implemented automatically by the device. After setting the zero gap on the centre of the plate, the sample was placed in such an amount as to distribute the sample evenly over the surface of the cone after leaving the tip of the cone at the measuring

Table 1. The chemical composition of the tested lubricating greases

Tabela 1. Skład chemiczny badanych smarów plastycznych

\begin{tabular}{|c|c|c|c|}
\hline $\begin{array}{c}\text { Lubricating } \\
\text { grease }\end{array}$ & Base oil & Thickener & Modified additive \\
\hline \hline A & Abyssinian oil & modified amorphous silica (6\%) & - \\
\hline B & Abyssinian oil & modified amorphous silica (6\%) & Brad Chem 351(1.5\%) \\
\hline C & Abyssinian oil (60\%) and SpectraSyn oil (40\%) & modified amorphous silica (7\%) & - \\
\hline D & Abyssinian oil (60\%) and SpectraSyn oil (40\%) & modified amorphous silica (7\%) & Brad Chem 351 (1.5\%) \\
\hline E & Abyssinian oil (60\%) and paraffin oil (40\%) & modified amorphous silica (8\%) & - \\
\hline
\end{tabular}

Table 2. The physicochemical properties of the tested mixtures of oils

Tabela 2. Właściwości fizykochemiczne zastosowanych mieszanin olejów

\begin{tabular}{|l|c|c|c|c|c|}
\hline \multirow{2}{*}{ Mixtures of oils } & $\begin{array}{c}\text { Oxidation } \\
\text { stability at } \mathbf{8 0}^{\circ} \mathbf{C}\end{array}$ & Pour point & Flash point & $\begin{array}{c}\text { Kinematic } \\
\text { viscosity at 40 }\end{array}$ & $\begin{array}{c}\text { Kinematic } \\
\text { viscosity at } \mathbf{1 0 0}^{\circ} \mathbf{C}\end{array}$ \\
\cline { 2 - 7 } & {$[\mathrm{h}]$} & \multicolumn{2}{|c|}{$\left[{ }^{\circ} \mathrm{C}\right]$} & \multicolumn{2}{|c|}{$\left[\mathrm{mm}^{2} / \mathrm{s}\right]$} \\
\hline \hline Abyssinian oil & 33.15 & -13 & 292 & 47.64 & 10.16 \\
\hline Abyssinian oil (60\%) and SpectraSyn oil (40\%) & 18.22 & -16 & 272 & 138.44 & 21.98 \\
\hline Abyssinian oil (60\%) and paraffin oil (40\%) & 29.09 & -13 & 262 & 59.41 & 9.68 \\
\hline
\end{tabular}


position. The test temperature was then set. The tests were carried out at $20^{\circ} \mathrm{C}$. Then the shear rate range in which the tests were carried out $\left(0.01-100 \mathrm{~s}^{-1}\right)$ and the measuring intervals in which the data were gathered (the number of measuring points, total duration of the measurement, and frequency of data collection) have been established experimentally. For the measurements of flow curves, a logarithmic curve was used to gather more points at the beginning of the range, which was decisive in determining the yield point, among other things. The tests were carried out for lubricating compositions with different base oils with the same thickener and modified additive (Drabik et al., 2018c; Kozdrach and Skowronski, 2018, 2019).

Four rheological models were used to describe the flow curves of the tested lubricating compositions, including the yield point: Bingham, Casson, Herschel-Bulkley, and Tscheuschner. The Casson model describes the flow curves of nonlinear viscoelastic fluids and is described as follows (Venkatesan et al., 2013; Siddiqui et al., 2015; Adewale et al., 2017):

$$
\tau^{1 / 2}=\tau_{0}^{1 / 2}+\left(\eta_{\infty} \cdot \gamma\right)
$$

where:

$\tau-$ is the shear stress $[\mathrm{Pa}]$,

$\tau_{0}-$ is the yield point $[\mathrm{Pa}]$,

$\eta_{\infty}-$ is the structural viscosity of grease $[\mathrm{Pa} \cdot \mathrm{s}]$ and

$\gamma-$ is the shear rate $[1 / \mathrm{s}]$.

The Bingham model describes the dependence of shear stress from shear rate in a linear method (Maciel et al., 2009; Talon et al., 2014; Feys et al., 2007; Frigaard et al., 2017):

$$
\tau=\tau_{0}+\eta_{p} \cdot \gamma
$$

where:

$\tau-$ is the shear stress [Pa],

$\eta_{p}-$ is the structural viscosity of grease $[\mathrm{Pa} \cdot \mathrm{s}]$,

$\tau_{0}-$ is the yield point $[\mathrm{Pa}]$ and

$\gamma-$ is the shear rate $\left[\mathrm{s}^{-1}\right]$.

The Herschel-Bulkley model is the simplest model for describing the flow curves of nonlinear viscoelastic fluids (Gavrilov et al., 2017; Chauhan et al., 2018; Jeon and Hodges, 2018):

$$
\tau=\tau_{0}+k \cdot \gamma_{n}
$$

where:

$\tau-$ is the shear stress [Pa],

$\tau_{0}-$ is the yield point $[\mathrm{Pa}]$,

$k-$ is the coefficient of consistency $\left[\mathrm{Pa} \cdot \mathrm{s}^{2}\right]$,

$\gamma-$ is the shear rate $\left[\mathrm{s}^{-1}\right]$ and

$n-$ is the coefficient of flow [-].

The Tscheuschner rheological model describes the flow curve of nonlinear viscoelastic fluids (Duhan et al., 2016; Santos et al., 2017; Ojewumi et al., 2018):

$$
\tau=\gamma\left(\eta_{\infty}+\tau_{0} / \gamma+n_{b} /\left(\gamma / \gamma_{b}\right)^{n}\right)
$$

where:

$\tau-$ is the shear stress $[\mathrm{Pa}]$,

$\tau_{0}-$ is the yield point $[\mathrm{Pa}]$,

$\gamma-$ is the shear rate $\left[\mathrm{s}^{-1}\right]$,

$n-$ is the coefficient of flow [-],

$\eta_{\infty}-$ is the structural viscosity of grease $[\mathrm{Pa} \cdot \mathrm{s}]$,

$\gamma_{b}-$ is the shear rate $\left[\mathrm{s}^{-1}\right]$ and

$n_{b}-$ is the coefficient of flow [-].

\section{Results of the research}

The results of the rheological tests (the dependence of shear stress on shear rate, i.e. flow curves) and the calculated values of the rheological parameters using the four rheological models - Bingham, Herschel-Bulkley, Casson, and Tscheuschner - for the selected lubricating greases with different base oils are presented below. The flow curves were obtained for the tested lubricating compositions using the above-mentioned rheological models, which are presented in Figs. 1-5.

The rheological parameters used to describe the flow curves of the tested lubricating greases are presented in Table 3.

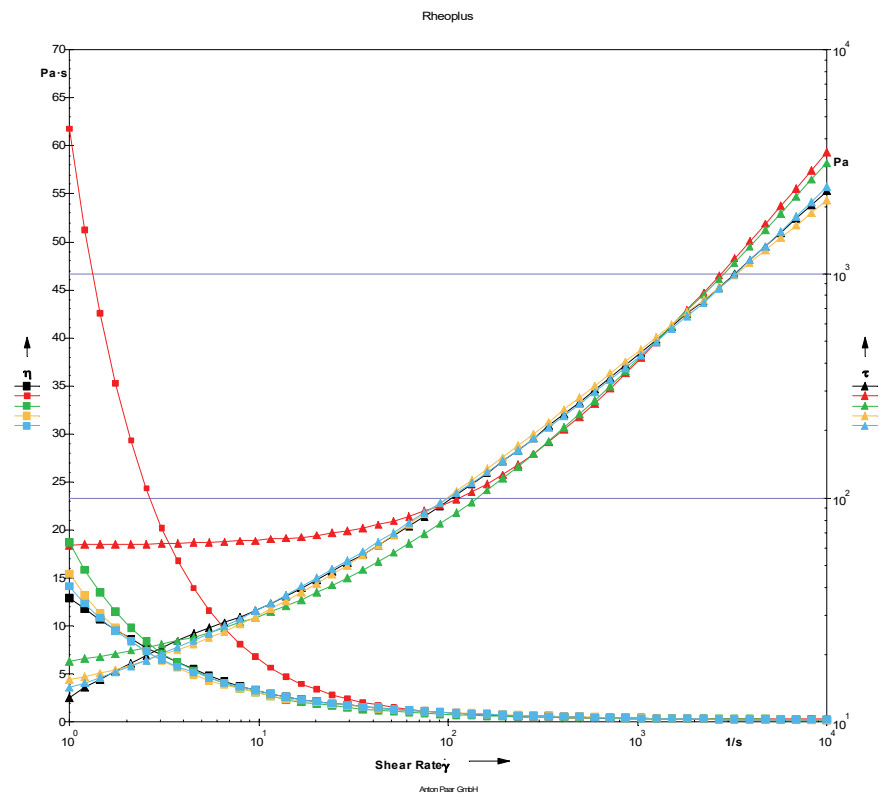

Fig. 1. The flow curves and viscosity curves for grease A using a rotational rheometer: experimentally (black), the curve fitted to the Casson model (red), the curve fitted to the Herschel-Bulkley model (green), the curve fitted to the Bingham model (yellow), and the curve fitted to the Tscheuschner model (blue)

Rys. 1. Krzywe płynięcia i krzywe lepkościwyznaczone dla smaru A za pomoca reometru rotacyjnego: doświadczalnie (czarny), krzywa dopasowana modelem Cassona (czerwony), krzywa dopasowana modelem Herschela-Bulkleya (zielona), krzywa dopasowana modelem Binghama (żółty) oraz dopasowana modelem Tscheuschnera (niebieski) 


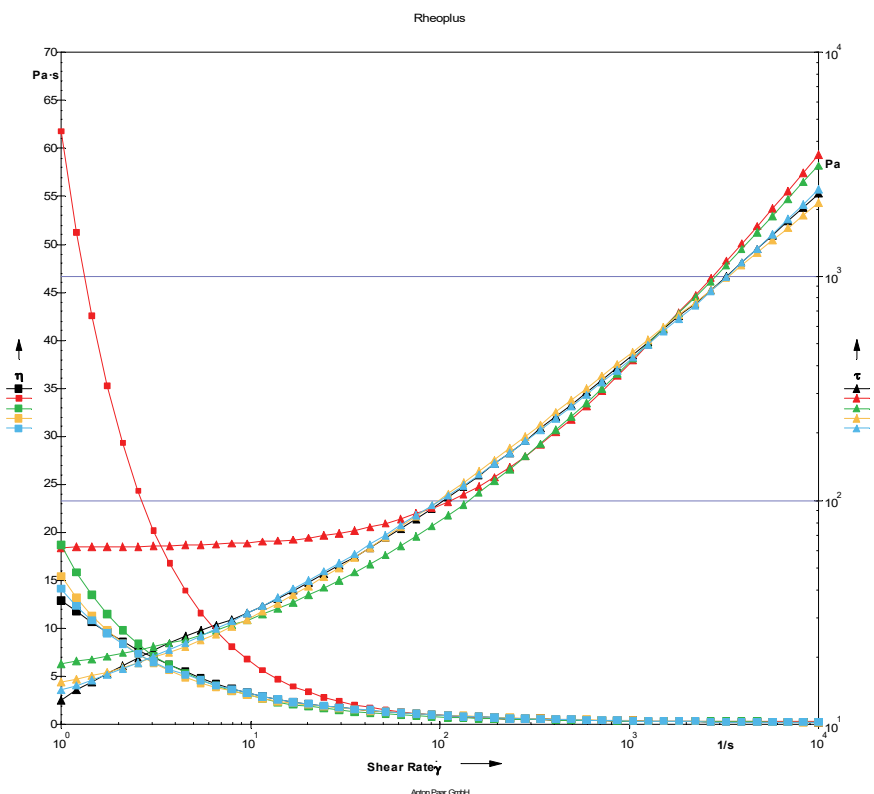

Fig. 2. The flow curves and viscosity curves for grease B using a rotational rheometer: experimentally (black), the curve fitted to the Casson model (red), the curve fitted to the Herschel-Bulkley model (green), the curve fitted to the Bingham model (yellow), and the curve fitted to the Tscheuschner model (blue)

Rys. 2. Krzywe płynięcia i krzywe lepkościwyznaczone dla smaru B za pomocą reometru rotacyjnego: doświadczalnie (czarny), krzywa dopasowana modelem Cassona (czerwony), krzywa dopasowana modelem Herschela-Bulkleya (zielona), krzywa dopasowana modelem Binghama (źółty) oraz dopasowana modelem Tscheuschnera (niebieski)

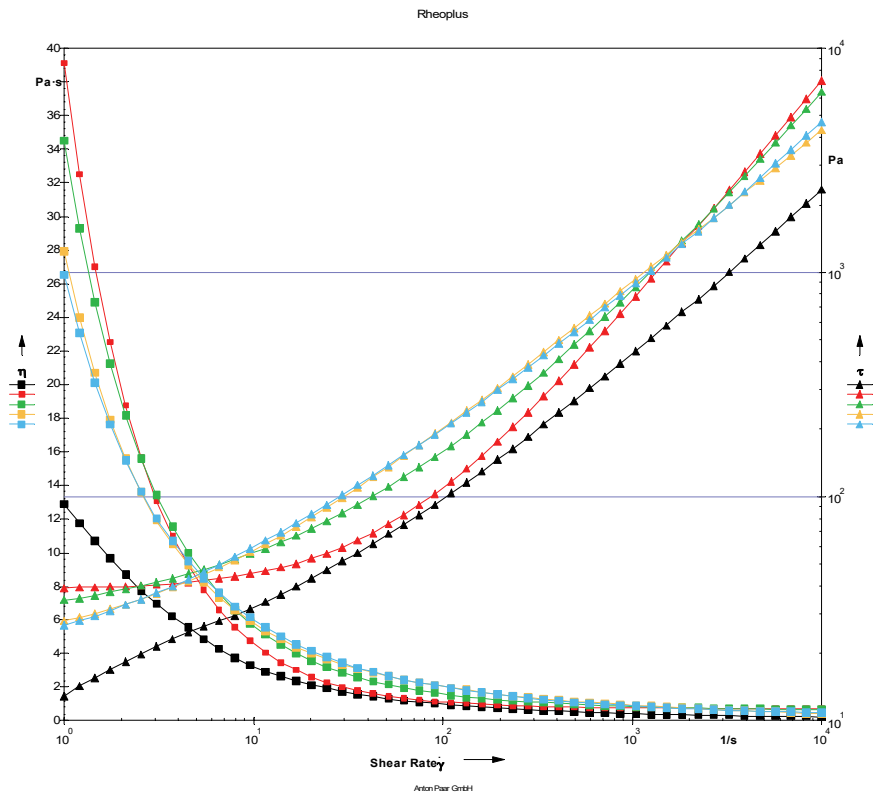

Fig. 4. The flow curves and viscosity curves for grease D using a rotational rheometer: experimentally (black), the curve fitted to the Casson model (red), the curve fitted to the Herschel-Bulkley model (green), the curve fitted to the Bingham model (yellow), and the curve fitted to the Tscheuschner model (blue)

Rys. 4. Krzywe płynięcia i krzywe lepkościwyznaczone dla smaru D za pomocą reometru rotacyjnego: doświadczalnie (czarny), krzywa dopasowana modelem Cassona (czerwony), krzywa dopasowana modelem Herschela-Bulkleya (zielona), krzywa dopasowana modelem Binghama (źólty) oraz dopasowana modelem Tscheuschnera (niebieski)

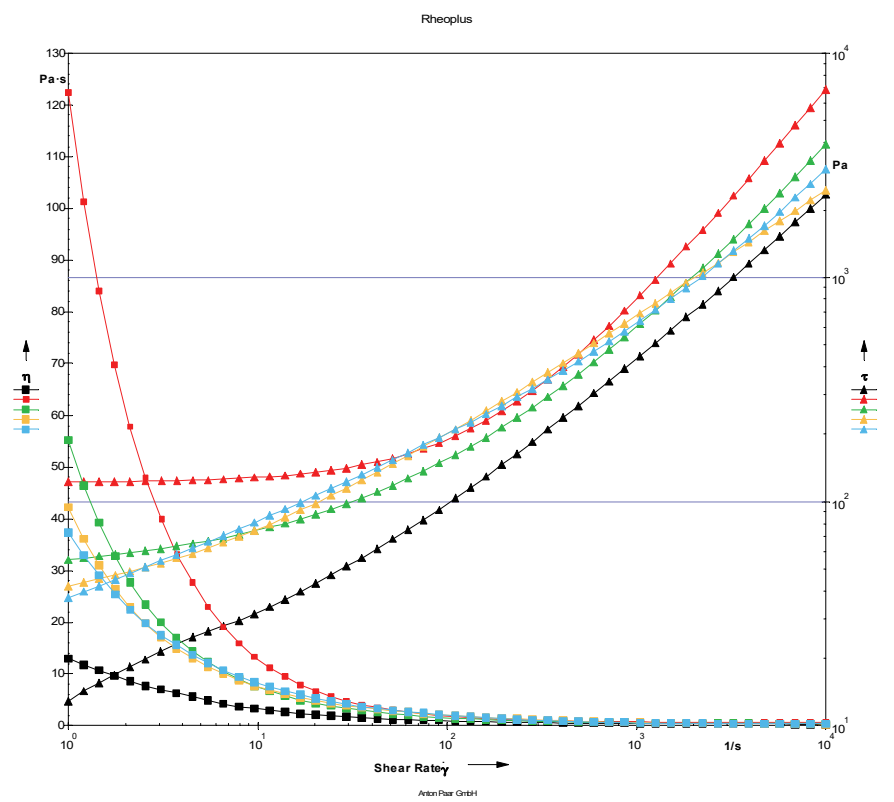

Fig. 3. The flow curves and viscosity curves for grease $\mathrm{C}$ using a rotational rheometer: experimentally (black), the curve fitted to the Casson model (red), the curve fitted to the Herschel-Bulkley model (green), the curve fitted to the Bingham model (yellow), and the curve fitted to the Tscheuschner model (blue)

Rys. 3. Krzywe płynięcia i krzywe lepkości wyznaczone dla smaru C za pomocą reometru rotacyjnego: doświadczalnie (czarny), krzywa dopasowana modelem Cassona (czerwony), krzywa dopasowana modelem Herschela-Bulkleya (zielona), krzywa dopasowana modelem Binghama (żółty) oraz dopasowana modelem Tscheuschnera (niebieski)

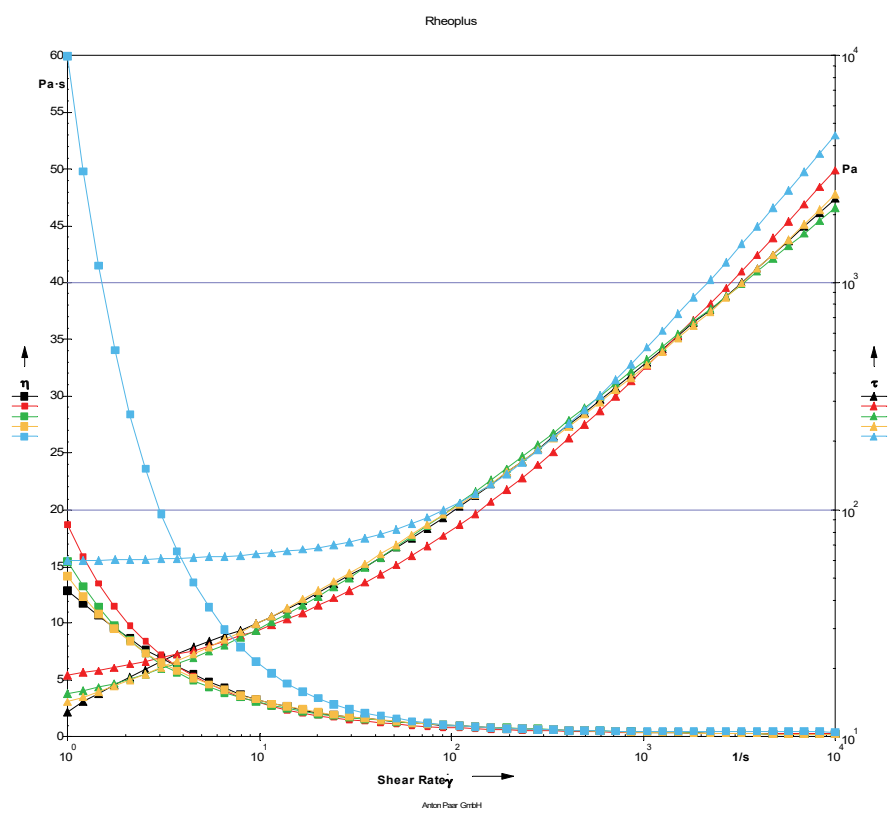

Fig. 5. The flow curves and viscosity curves for grease E using a rotational rheometer: experimentally (black), the curve fitted to the Casson model (red), the curve fitted to the Herschel-Bulkley model (green), the curve fitted to the Bingham model (yellow), and the curve fitted to the Tscheuschner model (blue)

Rys. 5. Krzywe płynięcia i krzywe lepkościwyznaczone dla smaru E za pomocą reometru rotacyjnego: doświadczalnie (czarny), krzywa dopasowana modelem Cassona (czerwony), krzywa dopasowana modelem Herschela-Bulkleya (zielona), krzywa dopasowana modelem Binghama (żółty) oraz dopasowana modelem Tscheuschnera (niebieski) 
Table 3. The basic parameters of rheological models describing the flow curves

Tabela 3. Podstawowe parametry modeli reologicznych opisujące krzywe płynięcia

\begin{tabular}{|c|c|c|c|c|c|c|c|c|c|c|c|c|c|c|}
\hline \multirow{2}{*}{ Greases } & $a$ & $b$ & \multicolumn{2}{|r|}{$p$} & $R^{2}$ & $s$ & $\tau_{0}$ & $\eta \infty$ & \multirow{2}{*}{$\frac{\eta_{p}}{[\mathrm{~Pa} \cdot \mathbf{s}]}$} & \multirow{2}{*}{$\frac{k}{[\mathrm{~Pa} \cdot \mathrm{s}]}$} & \multirow{2}{*}{$\begin{array}{c}n \\
{[-]}\end{array}$} & \multirow{2}{*}{$\begin{array}{c}\tau_{y} \\
{[\mathrm{~Pa}]}\end{array}$} & \multirow{2}{*}{$\begin{array}{c}\eta_{b} \\
{[\mathrm{~Pa} \cdot \mathrm{s}]}\end{array}$} & \multirow{2}{*}{$\begin{array}{c}\gamma_{b} \\
{[1 / s]}\end{array}$} \\
\hline & {$[-]$} & {$[-]$} & & {$[-]$} & {$[-]$} & {$[\mathrm{Pa}]$} & {$[\mathrm{Pa}]$} & {$[\mathrm{Pa} \cdot \mathrm{s}]$} & & & & & & \\
\hline \multicolumn{15}{|c|}{ Casson model } \\
\hline A & 3.7991 & 0.52170 & & 2 & 0.911 & 168.39 & 14.433 & 0.27219 & - & - & - & - & - & - \\
\hline B & 6.7971 & 0.47529 & & 2 & 0.829 & 121.98 & 61.351 & 0.22590 & - & - & - & - & - & - \\
\hline $\mathrm{C}$ & 9.4927 & 0.66693 & & 2 & 0.961 & 225.83 & 90.110 & 0.44480 & - & - & - & - & - & - \\
\hline $\mathrm{D}$ & 5.1179 & 0.74954 & & 2 & 0.883 & 384.33 & 26.193 & 0.56181 & - & - & - & - & - & - \\
\hline E & 6.8654 & \multicolumn{2}{|l|}{0.55772} & 2 & 0.900 & 222.45 & 47.133 & 0.31105 & - & - & - & - & - & - \\
\hline \multicolumn{15}{|c|}{ Bingham model } \\
\hline A & 17.952 & 0.99338 & & - & 0.970 & 4.003 & 17.952 & 0.99338 & 0.3218 & - & - & - & - & - \\
\hline B & 61.351 & 0.34275 & & - & 0.954 & 235.940 & 46.200 & 0.34275 & 0.0934 & - & - & - & - & - \\
\hline $\mathrm{C}$ & 121.340 & 0.67813 & & - & 0.837 & 458.890 & 121.340 & 0.67813 & 0.2345 & - & - & - & - & - \\
\hline $\mathrm{D}$ & 38.315 & 0.71031 & & - & 0.770 & 538.370 & 38.315 & 0.71031 & 0.2692 & - & - & - & - & - \\
\hline $\mathrm{E}$ & 59.376 & \multicolumn{2}{|l|}{0.43796} & - & 0.781 & 328.560 & 59.376 & 0.43796 & 0.1278 & - & - & - & - & - \\
\hline \multicolumn{15}{|c|}{ Herschel-Bulkley model } \\
\hline A & 11.671 & 3.7634 & \multicolumn{2}{|c|}{0.35212} & 0.993 & 45.672 & 11.671 & - & - & 9.276 & 0.43 & - & - & - \\
\hline B & 42.913 & 4.9287 & & 0.6635 & 0.999 & 21.028 & 42.913 & - & - & 37.453 & 0.38 & - & - & - \\
\hline $\mathrm{C}$ & 86.944 & 9.0401 & & .67203 & 0.998 & 44.638 & 86.944 & - & - & 83.277 & 0.36 & - & - & - \\
\hline $\mathrm{D}$ & 20.151 & 7.7066 & & .43456 & 0.997 & 66.100 & 20.151 & - & - & 18.811 & 0.28 & - & - & - \\
\hline $\mathrm{E}$ & 30.073 & 12.055 & & .57614 & 0.981 & 96.512 & 30.073 & - & - & 27.235 & 0.48 & - & - & - \\
\hline & & & & & & & heuschne & model & & & & & & \\
\hline A & 6.84 & 0.16 & 7.18 & 0.51 & 0.99 & 18.6 & 6.838 & 0.16221 & - & - & - & 2.44 & 0.0645 & 84.3 \\
\hline B & 39.5 & 0.09 & 6.95 & 0.58 & 0.99 & 9.29 & 39.485 & 0.09297 & - & - & - & 26.8 & 0.0234 & 88.1 \\
\hline $\mathrm{C}$ & 77.8 & 0.23 & 14.4 & 0.56 & 0.99 & 27.9 & 77.802 & 0.22864 & - & - & - & 67.4 & 0.1446 & 64.2 \\
\hline $\mathrm{D}$ & 15.4 & 0.23 & 10.9 & 0.59 & 0.99 & 20.8 & 15.367 & 0.22846 & - & - & - & 11.8 & 0.1459 & 68.7 \\
\hline $\mathrm{E}$ & 4.75 & 0.21 & 32.3 & 0.37 & 0.99 & 39.7 & 4.7531 & 0.20867 & - & - & - & 2.28 & 0.1267 & 56.8 \\
\hline
\end{tabular}

The diagrams and data presented in Table 3 illustrate the experimentally determined flow curves of the tested lubricating compositions and the calculated parameters and correlation coefficients using the four rheological models - Casson, Bingham, Herschel-Bulkley, and Tscheuschner. For grease A, which was not modified with the additive of $\mathrm{BCH}$ (Fig. 1), the best mapping of the flow curve determined experimentally was obtained using the Herschel-Bulkley and Tscheuschner models, which were characterised by high correlation coefficients (Table 3),whilst the Casson and Bingham models did not describe the flow curve of this grease as well. Significant differences were found in the yield point values for this composition as determined by the rheological models. Even for the models with the highest correlation coefficients (Herschel-Bulkley and Tscheuschner), these values differed significantly. For grease $\mathrm{B}$, modified by the additive of $\mathrm{BCH}$ (Fig. 2), the Herschel-Bulkley model, as well as the Bingham and Tscheuschner models, described the properties of grease $\mathrm{B}$ very well, as evidenced by the correlation coefficients of the resulting curves (Table 3). However, the Casson model did not describe the curve with sufficient precision. The yield point determined for this grease using the rheological models with the best fitto the experimental data vary slightly. For example, the yield point calculated from the Bingham model was $46.20 \mathrm{~Pa}$, whilst from the Herschel-Bulkley model it was $42.913 \mathrm{~Pa}$ and from the Tscheuschner model $39.485 \mathrm{~Pa}$. The yield point calculated from the Casson model was $61.351 \mathrm{~Pa}$, but the match of this model to the experimental data was insufficient (the correlation coefficient was 0.829 [-]). In the case of grease C, whose base was a mixture of vegetable oil and synthetic oil and which was modified with the additive of BCH (Fig. 3), the Tscheuschner and Herschel-Bulkley models most preferably described the flow curve, as evidenced by the correlation coefficient, 0.99 [-].The Casson model also described the curve flow well, because the correlation coefficient was $0.961[-]$, though the Bingham model did not describe the curve flow 
sufficiently, because it had a correlation coefficient of only 0.837 [-] (Table 3).

Although the Tscheuschner, Herschel-Bulkley, and Casson models described the flow curve for this composition well, a significant difference can be seen in the yield point values for these three rheological models. The yield point was calculated from the Casson model to be $90.11 \mathrm{~Pa}$, which was approx. 3.166 $\mathrm{Pa}$ higher than the yield point value calculated using the Herschel-Bulkley model. Likewise, the yield point calculated from the Tscheuschner model was $77.802 \mathrm{~Pa}$, which was about $10.52 \%$ and $13.66 \%$ lower than the yield point values calculated from the Herschel-Bulkley and Casson models, respectively. Although the value of this parameter calculated using the Bingham model had the highest value of $121.34 \mathrm{~Pa}$, this model did not fit the experimental data sufficiently. For grease $\mathrm{D}$, prepared with a mixture of vegetable and synthetic oils as the base and modified with the additive of BCH (Fig. 4), the flow curve was best described by the Herschel-Bulkley and Tscheuschner models, as evidenced by their correlation coefficients: 0.997 [-] and 0.99 [-], respectively. The Casson model and the Bingham model did not sufficiently describe the flow curve of grease $\mathrm{D}$ because the correlation coefficients were 0.883 [-] and 0.770 [-], respectively (Table 3 ). For this lubricant, the yield point calculated from the Herschel-Bulkley model was $20.151 \mathrm{~Pa}$, which was approx. 23.74\% higher than that of the Tscheuschner model. The highest value for this parameter (38.315 Pa) was found using the Bingham model. However, this model was characterised by a low correlation coefficient in relation to the data obtained through the experiments. The yield point calculated from the Casson model was 26.193 Pa, but this model also does not sufficiently describe the flow curve of grease D (correlation coefficient: 0.883 [-]).

For the lubricating composition based on a mixture of vegetable and mineral oil (Fig. 5, grease E), the most preferable models to describe the flow curves and to calculate the yield point were the Herschel-Bulkley and Tscheuschner models, because in both cases the correlation coefficients were relatively high (0.981 [-] and 0.99 [-], respectively). The Casson model did not sufficiently describe the flow curve (correlation coefficient: $0.900[-])$. However, the Bingham model was characterised by a unique low correlation coefficient for grease E: 0.781 [-]. It was found that the yield point for this composition calculated from the rheological models differed significantly, though it fit the experimental data well. For example, the yield point value calculated from the Tscheuschner model was $4.7531 \mathrm{~Pa}$, from the Herschel-Bulkley model $30.073 \mathrm{~Pa}$, and from the Casson model 47.133 Pa. However, in the case of the Bingham model, with the weakest fit to the experimental data, the yield point was $59.376 \mathrm{~Pa}$. The test results for grease $\mathrm{E}$ were inconclusive, which testifies to the heterogeneity of the tested sample.

\section{Conclusion}

The rheological properties of a lubricating grease are influenced by the type of base oil, thickener, and additives in the grease, its production technology, and the conditions in which the grease was used. The interaction between the thickener, additive, and base oil molecules changes along with changes in the type of base oil making up the dispersion phase of the lubricating composition. The type of base oil affects the structural viscosity and the yield point. The temperature at which grease is produced and the rate at which it is cooled have a significant influence on the stability of the grease structure and the shape of its basic rheological parameters. To enhance this structure and make it more homogeneous and resistant to external factors, base oils which change the interfacial free energy between the dispersion phase and individual particles of the dispersed phase, within the required range and to the necessary degree, are used.

The particles of the lubricating grease thickener, which are basically colloidal solutions, are several nanometres in diameter; therefore, the type of dispersion phase significantly influences the structural viscosity and the yield point of the tested compositions.

The shear stress (yield point) changes depending on the type of dispersion phase used. This proves that the use of a base oil with the appropriate functional properties does not weaken, but reinforces the spatial structure of a lubricating composition. This is key when selecting construction parameters for the design of a central lubrication system using lubricants with a vegetable oil base.

The aim of the work was to obtain the flow curves of selected lubricating greases and approximate the results of measurements with rheological models in order to calculate the value of rheological parameters, including the yield point. The models were selected for the highest correlation coefficient.

Evaluating the rheological parameters using the HerschelBulkley model and linear regression led to a lower yield point value with a high correlation coefficient. The Bingham model returned the highest yield point value, but with significantly variable correlation coefficients depending on the composition of the greases. These results could be due to the fact that the dependence of shear stress on the shear rate for lubricating greases was linear in this model. For the Tscheuschner model, the lowest values of the yield point were obtained with a high correlation coefficient. The Casson model, in turn, yielded intermediate values of the yield point between the Tscheuschner and Herschel-Bulkley models and lower values than the Bingham model with a relatively high correlation coefficient. For all tested lubricating greases, the Tscheuschner and Herschel-Bulkley models most effectively approximated 
the test results; the Casson model ensured relatively high correlation coefficient values at intermediate yield point values; and the Bingham model provided very high yield point values with a wide range of correlation coefficient values, which does not sufficiently approximate the test results.

These results lead to the following conclusions:

- The rheological properties of the tested lubricating compositions were significantly changed depending on the type of base oil used.

- The base oils used in the experiment acted synergistically with the modified additive and the silica thickener, enhancing the rheological parameters of the lubricating compositions.

- The degree of changes in yield point depends on the chemical structure and physicochemical properties of the base oil and is shaped by intermolecular interactions, mainly van der Waals forces, and the influence of the modified additive and other components of the lubricating composition. It is useful to carry out such research in order to explain the mechanism of the effective action of base oils on the basic rheological properties of lubricating greases, including the yield point.

The project was co-financed by the European Union from the European Regional Development Fund under the Smart Growth Programme POIR 04.01.02-00-0004/16.

\section{References}

Adewale F.J., Lucky A.P., Oluwabunmi A.P., Boluwaji E.F., 2017. Selecting the Most Appropriate Model for Rheological Characterization of Synthetic Based Drilling Mud, International Journal of Applied Engineering Research, 12(18): 7614-7629.

Bartz W.J., 1998. Lubricants and the environment, Tribology International, 31: 35-47. DOI: 10.1016/S0301-679X(98)00006-1.

Bartz W.J., 2006. Ecotribology: environmentally acceptable tribological practices. Tribology International, 39: 728-733. DOI: 10.1016/j.triboint.2005.07.002.

Beran E., 2008. Experience with evaluating biodegrability of lubricating base oils, Tribology International, 12:1212-1218, https:// doi.org/10.1016/j.triboint.2008.03.003

Casserly E., Langlais T., Springer S.P., Kumar A., 2004. The Effect of Base Oils on Thickening and Physical Properties of Lubricating Greases. Lube: The European Lubricants Industry Magazine -Tech, 115: 1-14.

Chauhan G., Verma A., Das A., Ojha K., 2018. Rheological studies and optimization of Herschel-Bulkley flow parameters of viscous karaya polymer suspensions using GA and PSO algorithms. Rheologica Acta, 57: 267-285. DOI: 10.1007/s00397-017-1060-x.

Cousseau T., Graça B.M., Campos A.V., Seabra J.H.O., 2012. Influence of grease rheology on thrust ball bearings friction torque. Tribol. Int., 46: 106-113. DOI: 10.1016/j.triboint.2011.06.010.

Delgado M.A., Franco J.M., Kuhn E., 2008. Effect of rheological behaviour of lithium greases on the friction process. Ind. Lubr Tribol., 60: 37-45. DOI: 10.1108/00368790810839927.

Delgado M.A., Sánchez M.C., Valencia C., Franco J.M., Gallegos C., 2005. Relationship among microstructure, rheology and processing of a lithium lubricating grease. Chem. Eng. Res. Des., 83 1085-1092. DOI: 10.1205/cherd.04311.
Delgado M.A., Valencia C., Sánchez M.C., Franco J.M., Gallegos C., 2006a. Influence of soap concentration and oil viscosity on the rheology and microstructure of lubricating greases. Ind. Eng. Chem. Res., 45: 1902-1910. DOI: 10.1021/ie050826f.

Delgado M.A., Valencia C., Sánchez M.C., Franco J.M., Gallegos C., 2006b. Thermorheological behaviour of a lithium lubricating grease. Tribol. Lett., 23: 47-54. DOI: 10.1007/s11249-006-9109-5.

De Laurentis N., Cann P., Lugt P.M. et al., 2017. The Influence of Base Oil Properties on the Friction Behaviour of Lithium Greases in Rolling/Sliding Concentrated Contacts. Tribology Letters, 65, 128: 1-16. DOI: 10.1007/s11249-017-0908-7.

Drabik J., Kozdrach R., Wrona M., Iłowska J., 2017. Use of diffusing wave and Raman spectroscopy for evaluation of paraffinic emulsions formed by homogenization. Przemyst Chemiczny, 12: 2544-2549. DOI: 10.15199/62.2017.12.31.

Drabik J., Trzos M., Kozdrach R., Wrona M., Wolszczak M., Duszyński G., Piątkowski M., 2018a. Modeling and evaluation of properties of lubricants used in the food industry. Przemyst Chemiczny, 12: 2200-2204. DOI: 10.15199/62.2018.12.39.

Drabik J., Trzos M., Pawelec E., Wrona M., Kozdrach R., Duszyński G., Piątkowski M., 2018b. Badanie właściwości użytkowych ekologicznych smarów wytworzonych na olejowych bazach roślinnych. Przemyst Chemiczny, 12: 2194-2199. DOI: 10.15199/62.2018.12.38.

Drabik J., Kozdrach R., Wolszczak M., Wrona M., 2018c. The proecological base oils of highly specialized lubricants. Przemyst Chemiczny, 9: 1538-1541. DOI: 10.30678/fjt.84884.

Duhan N., Sahu J.K., Naik S.N., 2016. Temperature dependent steady and dynamic oscillatory shear rheological characteristics of Indian cow milk (Desi) ghee. Journal of Food Science and Technology, 55(10): 4059-4066. DOI: 10.1007/s13197-018-3332-6.

Esteban B., Riba J.-R., Baquero G., Rius A., Puig R., 2012. Temperature dependence of density and viscosity of vegetable oils. Biomass Bioenergy, 42: 164-171. DOI: 10.1016/j. biombioe.2012.03.007.

Feys D., Verhoeven R., De Schutter G., 2007. Evaluation of Time Independent Rheological Models Applicable to Fresh SelfCompacting Concrete. Applied Rheology, 17: 56244-1-5624410. DOI: 10.1515/arh-2007-0018.

Fisher D., Jacobs G., Stratmann A., Burghardt G., 2018. Effect of base oil type in grease composition on the lubricating film formation in EHD contacts. Lubricants, 6(2): 32-42. DOI: 10.3390/ lubricants6020032

Florea O., Luca M., Constantinescu A., Florescu D., 2006. The influence of lubricating fluid type on the properties of biodrgradable greases. Journal of Synthetic Lubrication, 19(4): 303-313. DOI: $10.1002 /$ jsl.3000190404.

Fox N.J., Stachowiak G.W., 2003. Boundary Lubrication Properties of Oxidized Sunflower Oil. Journal of the Society of Tribologistand Lubrication Engineers, 2: 15-20. DOI: 10.1023/B:TR IL.0000015203.08570.82

Frigaard I.A., Paso K.G., de Souza Mendes P.R., 2017. Bingham's model in the oil and gas industry. Rheologica Acta, 56: 259-282. DOI: 10.1007/s00397-017-0999-y.

Gavrilov A.A., Finnikov K.A., Podryabinkin E.V., 2017. Modeling of steady Herschel-Bulkley fluid flow over a sphere. Journal of Engineering Thermophysics, 26(2): 197-215. DOI: 10.1134/ S1810232817020060.

Iłowska J., Chrobak J., Grabowski R., Szmatoła M., Woch J., Szwach I., Drabik J., Trzos M., Kozdrach R., Wrona M., 2018. Designing Lubricating Properties of Vegetable Base Oils. Molecules, 8: 2025-2035. DOI: 10.3390/molecules23082025. Jamadar I., Vakharia D., 2016. Correlation of base oil viscosity 
in grease with vibration severity of damaged rolling bearings. Industrial Lubrication and Tribology, 70(2): 264-272. DOI: 10.1108/ILT-04-2016-0078.

Jeon Ch.-H., Hodges B.R., 2018. Comparing thixotropic and HerschelBulkley parameterizations for continuum models of avalanches and subaqueous debris flows,. Natural Hazards and Earth System Sciences, 18: 303-319. DOI: 10.5194/nhess-18-303-2018.

Kato N., Komiya H., Kimura A., Kimura H., 1998. Lubrication Life of Biodegradable Greases with Rapeseed Oil Base. Journal of the Society of Tribologist and Lubrication Engineers, 8: 19-25.

Kavehpour H.P., McKinley G.H., 2004. Tribo-rheometry: from gapdependent rheology to tribology. Tribol. Lett., 17: 327-335. DOI: 10.1023/B:TRIL.0000032471.06795.ea.

Kozdrach R., 2017. Wpływ montmorylonitu na wartość granicy płynięcia smaru plastycznego wytworzonego na bazie roślinnej. Nafta-Gaz, 9: 698-706. DOI: 10.18668/NG.2017.09.10.

Kozdrach R., 2018. The influence of dispersed type phase on tribological properties of lubricating greases to form on the linseed oil. Nafta-Gaz, 6: 471-478. DOI: 10.18668/NG.2018.06.08.

Kozdrach R., 2020. The influence of montmorillonite content on change the physicochemical properties of lubricating greases produced from vegetable base oil, Nafta-Gaz, no.4:270-278, doi: 10.18668/NG.2020.04.06

Kozdrach R., Skowroński J., 2018. The Application of Polyvinylpyrrolidone as a Modifier of Tribological Properties of Lubricating Greases Based on Linseed Oil. Journal of Tribology, 6: 06180-1-06180-7.

Kozdrach R., Skowronski J., 2019. The application of chitosan as a modifier for lubricating greases based on vegetable oil. Tribology in Industry, 3: 212-219.

Maciel G.F., Dos Santos H.K., Ferreira F.O., 2009. Rheological analysis of water clay compositions in order to investigate mudflows developing in canals. Journal of the Brazilian Society of Mechanical Sciences and Engineering, 31(1): 64-74. DOI: 10.1590/S1678-58782009000100010.

Martín-Alfonso J.E., Valencia C., Sánchez M.C., Franco J.M., Gallegos C., 2013. The effect of recycled polymer addition on the thermorheological behavior of modified lubricating greases. Polym. Eng. Sci., 53: 818-826. DOI: 10.1002/pen.23327.

Ojewumi M.E., Oyeyemi K.G., Emetere M.E., Okeniyi J.O., 2018. Data on the rheological behavior of cassava starch paste using different models. Data in Brief, 19: 2163-2177. DOI: 10.1016/j. dib.2018.06.112

Pham K.N., Petekidis G., Vlassopoulos D., Egelhaaf S.U., Poon W.C.K., Pusey P.N., 2008. Yielding behavior of repulsion- and attraction-dominated colloidal glasses. J. Rheol., 52: 649-676. DOI: 10.1122/1.2838255.

Sanchez R., Franco J.M., Delgado M.A., Valencia C., Gallegos C., 2009. Development of new green lubricating grease formulations based on cellulosic derivatives and castor oil. Green Chemistry, 11: 686-693. DOI: 10.1039/B820547G.
Santos P.H.S., Carignano M.A., Campanella O., 2017. Effect of Shear History on Rheology of Time-Dependent Colloidal Silica Gels. Gels, 3(4): 45-54. DOI: 10.3390/gels3040045.

Siddiqui A.M., Farooq A.A., Rana A., 2015. A Mathematical Model for the Flow of a Casson Fluid due to Metachronal Beating of Cilia in a Tube. The Scientific World Journal, 487819. DOI: $10.1155 / 2015 / 487819$.

Singh J., Kumar D., Tandon N., 2018. Rheological and film forming behavior of the developed nanocomposite greases under elastohydrodynamics lubrication regime. J. Tribol., 141: 021804. DOI: 10.1115/1.4041304.

Solomon M.J., Almusallam A.S., Seefeldt K.F., Somwangthanaroj A., Varadan P., 2001. Rheology of polypropylene/clay hybrid materials. Macromolecules, 34: 1864-1872. DOI: 10.1021/ma001122e.

Song Y., Zheng Q., Cao Q., 2009. On time-temperature-concentration superposition principle for dynamic rheology of carbon black filled polymers. J. Rheol., 53: 1379-1388. DOI: 10.1122/1.3216923.

Szmatoła M., Chrobak J., Grabowski R., Iłowska J., Woch J., Szwach I., Semeniuk I., Drabik J., Wrona M., Kozdrach R., Orlińska B., Grymel M., 2018. Spectroscopic Methods in the Evaluation of Modified Vegetable Base Oils from Crambe abyssinica. Molecules, 11: 3243-3255.

Talon L., Auradou H., Hansen A., 2014. Effective rheology of Bingham fluids in a rough channel. Frontiers in Physics, 2: 1-8. DOI: 10.3389/fphy.2014.00024.

Tuszyński W., Szczerek M., Michalczewski R., Osuch-Słomka E., Rogoś E., Urbański A., 2014. The potential of the application of biodegradable and nontoxic base oils for the formulation of gear oils - model and component scuffing tests. Lubrication Science, 26(5): 327-346. DOI: 10.1002/ls. 1262.

Venkatesan J., Sankat D.S., Hemalatha K., Yatim Y., 2013. Mathematical Analysis of Casson Fluid Model for Blood Rheology in Stenosed Narrow Arteries. Journal of Applied Mathematics, 11: 1-11. DOI: 10.1155/2013/583809.

Wyss H.M., Miyazaki K., Mattsson J., Hu Z., Reichman D.R., Weitz D.A., 2007. Strain-rate frequency superposition: a rheological probe of structural relaxation in soft materials. Phys. Rev. Lett., 98: 238303. DOI: 10.1103/PhysRevLett.98.238303.

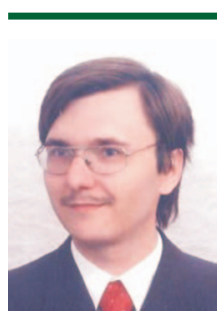

Rafał KOZDRACH MSc.

Łukasiewicz Research Network - The Institute for Sustainable Technologies

K. Pulaski Street 6/10

26-600 Radom

E-mail: rafal.kozdrach@itee.lukasiewicz.gov.pl 